\title{
Sedekah QR (SQR): Charity System in Modern Era
}

\author{
Muhammad Al Faridho Awwal ${ }^{1 *}$, Dewi Wahyu Setyo Rini ${ }^{2)}$ \\ ${ }^{1,2}$ Faculty Islamic Economics and Business, Universitas Islam Negeri Sunan Kalijaga, Yogyakarta \\ * Email correspondence: mafaalial@gmail.com
}

\begin{abstract}
Badan Amil Zakat Nasional (Baznas) has launched a donation system with QR code on Friday, December 22th 2017. Baznas' Deputy Chief, Arifin Purwakananta said the usage of QR code was the first in alms services. Other than using QR code, Baznas also cooperated with various online multipayment services such as Go-Pay and OVO. Observing such trends, by using research with qualitative and quantitative approach and modifying both Theory of Planned Behavior and Technology Acceptance Models, this research aims to formulate the concept of cashless alms donation payment done by every feasible mosque and to discover society's interest toward alms donation using QR code. Therefore, there need to be a synergy between Otoritas Jasa Keuangan (OJK) as financial transaction supervisor and Dewan Masjid Indonesia (DMI) as the highest position in mosques' management in Indonesia. This direct collection approach done by this service is expected to increase mosques' welfare and the communities around mosques so that the equality of welfare to all mosques can happen
\end{abstract}

Keywords: Cashless Donation, Mosque, Mosque's Welfare

Citation suggestions: Awwal, M. A., \& Rini, D. W. (2021). Sedekah QR (SQR): Charity System in Modern Era. Jurnal Ilmiah Ekonomi Islam, 7(02), 942-952. doi: http://dx.doi.org/10.29040/jiei.v7i2.2197

DOI: http://dx.doi.org/10.29040/jiei.v7i2.2197

\section{INTRODUCTION}

Nowadays, the development of Islamic financial instruments that are also known as Islamic philanthropy is starting to have more acknowledgement from many parties. Islamic philanthropy's potentials almost reach 217 Trillion Rupiahs in which the government tries to seek strategies to optimized those potentials. In further observation, the potentials not only stops at zakat instruments, but also alms and infaq as well, knowing both of these instruments' characteristics which are the donations done are not limited to wealth that is possessed and the amount of wealth that needs to be given (in Zakat there are concepts of Nisab and Haul). Types of goods accumulated are not only limited to money and the transfer of fund doesn't have certain time limits, thus every Muslims can have the same chance.

The accumulation of alms and infaq fund usually identical to jam'iyah activities or Islamic social gatherings that involves a sizable amount of people. Mosques are one of the gathering places for Moslems to have their activities routinely with hearts and minds clearer than before (Suryanto, 2016). Mosques' roles become very strategic when related to mosques' characteristics that always bring peace to every individual. Knowing mosques becomes place to pray to God for Muslims, it is not surprising the place often becomes a gathering point to discuss problems that happen in the neighborhood. Therefore, mosque community become a community that has a strong foundation because of their mutual trust and unity. Moreover, in mosques usually there is a charismatic figure that is trusted by the community and therefore can potentially become a motivator that can influence and lead the people on that neighborhood in creating a prosperous community.

$10^{\text {th }}$ and $12^{\text {th }}$ Vice President of Indonesia Yusuf Kalla said that Indonesia has more than 800.000 mosques spread around the nation, and that's not counting all of them due to many mosques and prayer buildings that are not registered by the Religion Ministry. Data Bimas Islam Kementrian Agama Republik Indonesia of 2014 mentioned the number of mosques and prayer buildings were 731.095 which consists of 292.439 mosques and 438.656 prayer 
buildings. This number is more than the number of villages existing. According to Peraturan Kepala Badan Pusat Statistik No. 66 Tahun 2016 in regards to Kode Wilayah Kerja Statistik Tahun 2016, the number of villages in Indonesia reached 82.030. Thus, it can be said that every villages have more than one mosque or prayer buildings. Hence, mosque and prayer buildings have a big role in creating the welfare of the neighborhood.

The potential of alms accumulation in mosques and prayer buildings are so high, knowing the number of mosques in Indonesia is also high and also the amount of people that visited the mosques are not only the neighborhood. It is not rare for travelers to choose mosques to become their rest point not only to pray but also to rest for a while. The potential that mosques have in details are: 1) can help the government to decrease the number of poverties, 2) can decrease the government dependency toward foreign debt in executing poverty release programs, 3 ) can be used to help the people to be economically independent (Muhtadi, 2006). Seeing those potentials, there needs to improve mosques not only their financial sources, their innovations in accumulating infaq and alms, but also their empowerment toward the neighborhood.

If we're talking about innovation, especially innovation in accumulating funds nowadays, talking about technology becomes unavoidable. Indonesia is currently entering Industrial Revolution 4.0 era, in which almost every system of living controlled and defined by technology, including social funding. Even now there are already crowdfunding-based financial technology which is funding accumulation platforms used to fund an events or campaigns that happened. The surfacing of these systems is related to human conditions that progressively want everything to be instant, fast and efficient, thus the sudden rising fast of ride hailing services, online transactions, and multipayment as well. According to data from a research called The Opportunity of Indonesia pioneered by Temasek and Google, the rising of ecommerce in Indonesia by 2015 reached 18 million users from 92 million of online service users overall. From that number, by 2025 it can be predicted the number of online buyers in Indonesia will reach 119 million of people out of 215 million (Zaenudin, 2017).

The rise of e-commerce usage is also followed by the rising of e-wallet usage, in which e-wallet shown impressive growth in a short time. Merchants in Gopay networks increased 50 times from around 4,000 by May 2018 to 200,000 in November 2018. E-wallet is a money-saving place in a form of mobile app, so everyone can access the app whenever deemed necessary. The types of e-wallets are limited in accordance to the purpose of transactions. For example, Gopay is an e-wallet service from Gojek. This feature is not only limited for online transportations payment, but also for foods, phone balances, movie tickets, delivery services, and others, in which these services are currently become human needs in order for them to survive. Furthermore, this feature is also equipped with attractive promos and discounts that makes people interested in using these services. By 2017, Gopay active users reached 11 million people, while OVO active users reached 60 million people (Gumiwang, 2018).

These facts that becomes one of the reasons why innovations are needed in accumulating the funds of infaq and alms especially in neighborhood mosques, because nowadays society are inseparable with technology and their lifestyle that likes something fast and easy. Almost every people in productive age have these apps, even some individuals have more money saved in their e-wallet more than what they have on their physical wallet. Therefore, we try to formulate the concept in regard to alms payment in mosques synergized with e-wallet services. Knowing most of the society in productive age have tendency to save most of their money in electronic balances rather than printed money and more often to bring their smartphones than their wallets when they go to mosques. Started from the our restlessness when we wanted to donate some alms but we don't bring any money to donate, even though we have money in our e-wallets. We suggested to have the management of mosque's alms fund to be synergized with e-wallet services in which it is connected directly to the existing mosque's account, so that the transaction will be done directly to the mosque's management administration.

According to the research by Wahyuddin (2006) "Manajemen Penghimpunan dan Pendayagunaan Zakat, Infaq, Shadaqah (ZIS) dan Wakaf Uang Melalui Teknologi Informasi Pada LAZ PORTALINFAQ" stated that the management of ZIS and waqaf is relying on backed-up management system with sufficient information technology also in accumulation and utilization of zakat done by Portalinfaq using internet or information technology 


\section{Jurnal Ilmiah Ekonomi Islam, 7(02), 2021, 944}

makes it more easier for muzakki that have responsibility to give zakat.

In accordance to the research done by Nurmalasari (2018) "Faktor-faktor yang Mempengaruhi Minat Penggunaan T-Cash pada Mahasiswa Universitas Islam Indonesia", the method used in this research is quantitative research method by using double linear regression analytical technique. As for the result of said research shows that the trustability variable partially affecting positively toward the interest in using T-Cash. Meanwhile the perception of simplicity, utility and security are partially not affecting anything toward the interest in using T-Cash.

Then research done by Firdauzi (2016) "Pengaruh Kemampuan Finansial, Kemuduhan dan Perilaku Konsumen Terhadap Minat Penggunaan Uang Elektronik di Kota Yogyakarta". This research was a explorative study using quantitative approach. Analytical method used was Structural Equation Modeling (SEM). The result shows that the variable of financial capability is affecting significantly positive toward the simplicity for $54,7 \%$, the variable of simplicity affecting significantly positive toward the consumers behavior for $82,4 \%$, the variable of simplicity affecting significantly positive toward the interest for $66,8 \%$, the variable of consumers behavior affecting significantly positive toward the interest for $69,3 \%$

The next research which is research done by Rahayu (2018) "Pengaruh Presepsi Manfaat, Presepsi Kemudahan, Presepsi Risiko dan Inovasi Teknologi Terhadap Aplikasi Go-Pay dai PT. Gojek Indonesia”. Data gathering technique used by using questionnaires which then tested by using PLS and IBM SPSS Statistic program. Result shows that the perception of utility, simplicity and technological innovation affecting significantly positive toward the interest in using go pay. Meanwhile the perception of risks affecting negative toward the interest in using go pay. Then the variable of interest in using go pay affecting significantly positive in the usage of gopay.

Therefore, by using the past researches that the society nowadays have more interest in something easy and instant, including when it comes to payments. In the past researches we can also see there are many factors that can affecting society's interests toward e-payment system or applications. Thus we want to observe the society's interest toward epayment system or applications with quantitative approach, and also giving innovations and suggestions regarding the models of alms and infaq payments in mosque using electronic devices with qualitative approach supported by strong theory, this research is titled Sedekah QR (SQR) Solusi Sedekah Masa Kini.

SQR by default is not a new platform in and of itself, SQR is a form of accumulation services using QR Code where the barcode synergizes all accounts. Which means any amount of money that wanted to be transferred with using any accounts can be accessed by using one QR code. For the writers, the usage of QR code in every mosque that are integrated with many bank services can increases the amount of funds that can be accumulated.

\section{RESEARCH METHODOLOGY}

This research uses Mixed Methods, that is both quantitative and qualitative approach. Quantitative research used are by using modifications of Theory of Planned Behavior (TPB) which is a development of Theory of Reason Action (TRA) by Aizen (1991) and Technology Acceptance Model (TAM). TPB is accurately used to explain various behavior that were planned. As Aizen (1991) explained that 'TPB is suitable to explain any behavior which requires planning, such as entrepreneurship'. While TAM is one of the models that can be used to analyze factors that affecting whether a system is accepted. This model is firstly introduced by Fred Davis (1989). On qualitative research the researcher try to design a concept of bargaining system supported by strong theories with phenomenology approach.

\subsection{Framework}

TAM often used as theory that based previous researches like research done by Dreana (2012) "Analisis Faktor-Faktor yang Mempengaruhi Penerimaan Pengguna SIMAWEB di Fakultas Ekonomika dan Bisnis Universitas Diponegoro: Integrasi TAM dan TPB". The purpose of the research is to test the integrated model of TAM and TPB on the acceptance of SIMAWEB users in Faculty of Economics and Business Diponegoro University. In the previous years, Taylor and Todd (1995) tested the difference in the usage of technological information system from experienced users and unexperienced users in terms of its usage. The mixed model of TAM and TPB used in Taylor and Todd research often named as Augmented TAM. Experienced and inexperienced users different in many levels. In TAM, the variable of intention is influenced by two other 
variables that is perceived usefulness and perceived ease of use. Although, TAM does not put the influence of social factors and control factors on behavior. Even though in the further research it become known that both factors proven to have significant influence toward the behavior of information technology usage. Those factors also become determinant factor toward the behavior in theory of planned behavior (TPB).

In TPB, social factor or social influence called subjective norm proven to influence intention. Control factors in TPB is perceived behavior control that is modeled to influence both in intention and behavior. The integration of TAM and TPB is a theory that put both TPB factor into TAM model so that the disadvantage in TAM model that cannot control the behavior of information system can be avoided. That means the model of TAM and TPB can be used simultaneously to analyze the offer of a technology by calculating its behavior. (Ardhiani. 2015)

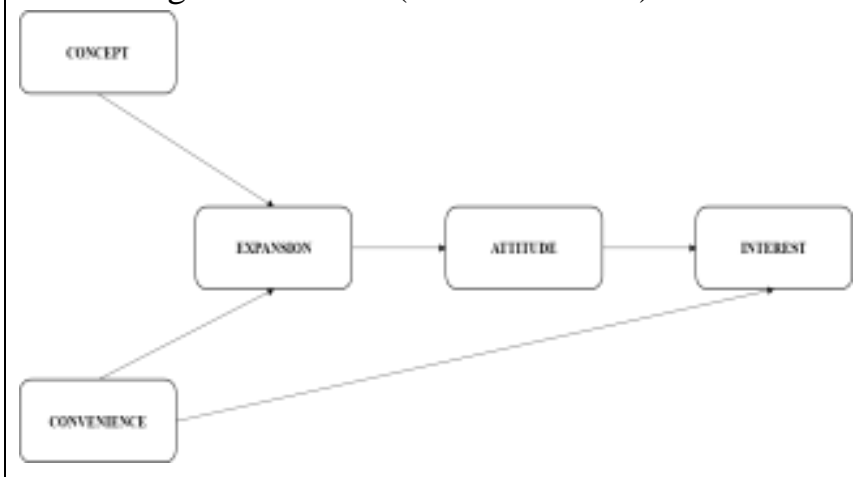

Figure 1. Quantitative Model Used

In the construction above the researcher tries to combine the construction of TPB and TAM. In model aboce research have a hypothesis supported by a number of theories, previous research and with his own rationale. In the theory of Agustiani (2009) mentioned that the concept of self heavily influenced someone's behavior. By knowing the concept of self, it is much easier to predict and understand their behavior. Fakhrurozi (2018) said in his thesis that ease of use is one of the factors in influencing the interest of students in using technology like mobile banking. Kusdani (2013) in his thesis said that attitudes affected positively toward the interest of the people in using internet services. Below is the hypothesis used in quantitative research:

H1: Perceived concept influenced positively toward the development of alms using online / cashless alms applications.

$\mathrm{H} 2$ : Perceived ease of use in using financial technology influenced positively toward the development of alms using online / cashless alms applications.

H3: Perceived of alms development using online / cashless alms applications influenced positively toward the attitude in the rise of alms online / cashless.

H4: The attitude in using alms online/cashless influenced toward the interest in using the online/ cashless alms applications.

Respondents taken is about 51 people with purposive random sampling analyzed with analytical knife of Structural Equation Modeling (SEM). SEM is a statistical tool used to solve hierarchal model simultaneously that cannot be solved using linear regression equation. SEM can also be interpreted as a combination of regression analysis and factor analysis. SEM can also be used to solve equation model with more than one attached variables and mutual influence. According to Ghozali (2008). SEM is an evolution from multiple equation model expanded from econometrics principle and combined with adjustment principle from psychology and sociology, SEM has appeared as integral part in managerial academical research.

In quantitative research with phenomenological approach, the researcher has hypothesis that the current generation especially millennials do not like using printed money proven by many reports from printed media to digital media. The usage of cashless money has also been supported by government agencies. Therefore, there need to be a way so that alms giving that initially done using printed money also need to be changed into cashless to answer the current problem.

\subsection{QR Alms: The Potential of Alms in Digital \\ Era}

Indonesia has entered digital 4.0 era, where almost every part of live has been digitalized, with no exception for Islam philanthropy. BAZNAS study center (2018) explained that the usage of digital technology has been included in the process of accumulation, distribution, management, and education of zakat. Platform that has been used for example the payment method on BAZNAS's website or apps. Furthermore, BAZNAS has cooperated with platforms such as e-commerce, online crowdfunding, digital teller machines and also QR codes in which BAZNAS teamed up with PT Gojek Indonesia and 
Bank BNI Syariah to access those services. Knowing nowadays people likes to use cashless money more.

The reason behind the rise of electronic money in Indonesia is none other than the involvement of Bank Indonesia's regulation in 2009. In 2014 Bank Indonesia also aggressively campaigned Gerakan Nasional Non Tunai (GNNT). As for the number of electronic money users has experienced sudden rise, with Bank Indonesia mentioned these data:

Table 1. Electronic Money Users

\begin{tabular}{|c|l|}
\hline Period & Number of Users \\
\hline $\mathbf{2 0 1 2}$ & 21.869 .946 \\
\hline $\mathbf{2 0 1 3}$ & 36.225 .373 \\
\hline $\mathbf{2 0 1 4}$ & 35.738 .233 \\
\hline $\mathbf{2 0 1 5}$ & 34.314 .795 \\
\hline $\mathbf{2 0 1 6}$ & 51.204 .580 \\
\hline $\mathbf{2 0 1 7}$ & 90.003 .848 \\
\hline $\mathbf{2 0 1 8}$ & 167.205 .578 \\
\hline
\end{tabular}

Source: Bank Indonesia, 2018

The data above shows significant rise every year, as for the electronic money services consists of two forms that is card-based and application-based/mobile payment. Below is the data from Bank Indonesia in regards to forms of electronic money available:

Table 2. Forms of Electronic Money in Indonesia

\begin{tabular}{|l|c|c|}
\hline \multicolumn{1}{|c|}{ Electronic Money } & $\begin{array}{c}\text { Card- } \\
\text { Based }\end{array}$ & $\begin{array}{c}\text { Application- } \\
\text { based /multi- } \\
\text { payment }\end{array}$ \\
\hline Mandiri E-toll & Yes & \\
\hline Indomaret Card & Yes & \\
\hline BCA Flazz & Yes & \\
\hline BNI Tapcash & Yes & \\
\hline BRI Brizzi & Yes & \\
\hline Mandiri E-cash & & Yes \\
\hline LINE Pay & & Yes \\
\hline Dompetku Indosat Ooredoo & & Yes \\
\hline XL Tunaiku & & Yes \\
\hline Doku Wallet & & Yes \\
\hline CIMB Rekening Ponsel & & Yes \\
\hline Nobu E-money & & Yes \\
\hline Sakuku BCA (QR code) & & Yes \\
\hline Finnet (QR code) & & Yes \\
\hline Telkomsel T-cash (NFC) & & Yes \\
\hline
\end{tabular}

These days payment using e-wallet is very attractive to society especially to people in productive age. Seeing the potential of mosques and the condition of teenagers nowadays that cannot be detached from technology, there need to be a system to improve the performance of mosques by utilizing the technology of e-wallet in increasing the awareness in giving alms. In this journal, the writer did not suggest to form a new fintech for the service in accumulating alms. However, here the writer suggests the existence of government policies to provide alms accumulation service to mosques using e-wallet that can directly goes to the mosques' account so that it can be used effectively by respective mosques. Below is the framework that the writer suggests for this service:

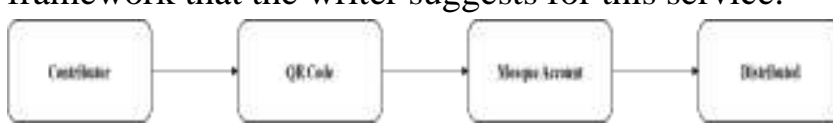

Figure 2. SQR Process

Source: The writer's analysis

In this research questions, the writer tries to analyze again in regards to the use of e-wallet service that can be used for alms accumulation in mosques. First of all we observe the facts that have been said above. People in productive age progressively move to cashless behavior. It means when people go to the mosques to pray (sholat, dzikir, iktikaf) it is an immaterial activity and thus they less likely to remember to bring printed money to donate, in addition to government supports toward cashless movement that has been said in the previous paragraphs.

It cannot be avoided that slowly but surely the modern society will reduce their usage of printed money as their main transaction tool. However, the modern society due to technological development cannot be separated from what is called gadget including smartphone. This thing can become a big opportunity for mosques if it is integrated with a cashless service when it comes to accumulating alms. With the integration the fund collected can be directly managed by the respective mosque for the sake of the people's welfare. The donators can just put out their smartphones then scan the QR codes available around the mosque just like how they scan QR codes for purchasing goods in other places, write the number of money that want to be donated then the money will directly goes to the mosque's account so that it can be managed effectively.

This service is expected to be integrated with all banks with one QR code that can directly charge the account so that the donators does not need to top up their fintech account first to donate like Go pay and 
OVO, so that there will not be problems such as not enough balance or did not top up the balance, because the money will be directly charged to the donator's main banking account. This service is expected to operate just like the application LinkAja that was launched in March 2019 by BUMN ministry. The service is a combination of electronic payment service and some state-owned enterprises (BUMN) but of course not only from electrical payment from BUMNowned banking but also all banking around the nation can hopefully be integrated as well.

In this service, there need to be coordination from the side of financial supervisory agency which is Otoritas Jasa Keuangan (OJK). Considering in this service, the SQR service integrated all banking to be integrated into one QR code that then will directly charge the donator's account and transferred to the mosque's account. So that in regards to the type of banking that is integrated in QR code is also be adjusted to the mosque's account that will be used. Therefore, other than the role of OJK in terms of monitoring regarding financial banking service, there need to also be monitoring from Dewan Masjid Indonesia (DMI) in the lowest hierarchy to coordinate the type of banking that will be used in the mosque. The choice of account will be adjusted to the type of banking that is available on those areas, but Syariah banking will be prioritized.

Moreover, there need to be coordination from DMI about the strategy on the fund distributions and which part that needs to be distributed, so hopefully from that when there are mosques that have excess funds they can help other mosques to maximize their programs. The funds that are saved in the mosque's account will be automatically integrated to DMI by OJK, so that the data regarding the amount of funds collected can be reported in order to minimalize moral hazards that might happened.

The use of QR codes can also developed a philanthropic and "show-off" attitude in giving alms, because the amount of money will not be revealed by anyone except the donators and the mosque's management. By this service hopefully it can increase the awareness of young people in regards to how important it is to donate and how to give welfare to mosques. QR codes will be given with appealing and clear designs, so that the people can understand the meaning of those codes. This service can be expected to increase the mosques' incomes to increase the welfare of said mosques.

\subsection{Analysis of Society Interest to the Launch of SQR}

Just like in business industry, relevant new conceptual-based researches need to have a survey regarding the level of society's acceptance by looking at society's interest in implementing the SQR scheme. Like Karim (2001) explained in law of demand, where the demand factor is influenced by society's interest in increasing the economic growth. The more interest society has in goods or services, the more their demands are in said goods or services. This is supported by the theory stated by Icek Ajzen and Martin Fishbein and Achmat in the research done by Ramdhani (2011) that stated that the determinant factor in individual's behavior is in their intentions in behaving. This theory is summarized that is then known as Theory of Reasoned Action or Theory of Planned Behavior like what we've stated above. Therefore, there need to be a test regarding SQR whether or not it will be relevant to be applied in millennial society especially those who are 17-37 years old.

This research took 51 respondents by using purposive sampling technique, in which respondents that can fill are only those who fulfill the standards required. As for the standards that the researcher set are the respondents visit the mosque at least once a week. The research is proposed by distributing the questionnaire which consists of several variables and questions. The research is done in order to figure out the interest of millennial society toward SQR plan. The test is done using the modification of Theory of Planned Behavior (TPB) scheme as the parameter of influence of society perception toward the interest in SQR, which then modified with the scheme of Technology Acceptance Modeling (TAM) as the parameter of the service's ease of use in which later on will affect the society's interest. Analytical tool used is Structural Equation Modelling (SEM) which measuers the effect of exogenous toward endogenous variable. Below is the fit model that the researcher has designed, using Smart PLS software ver. 3. 


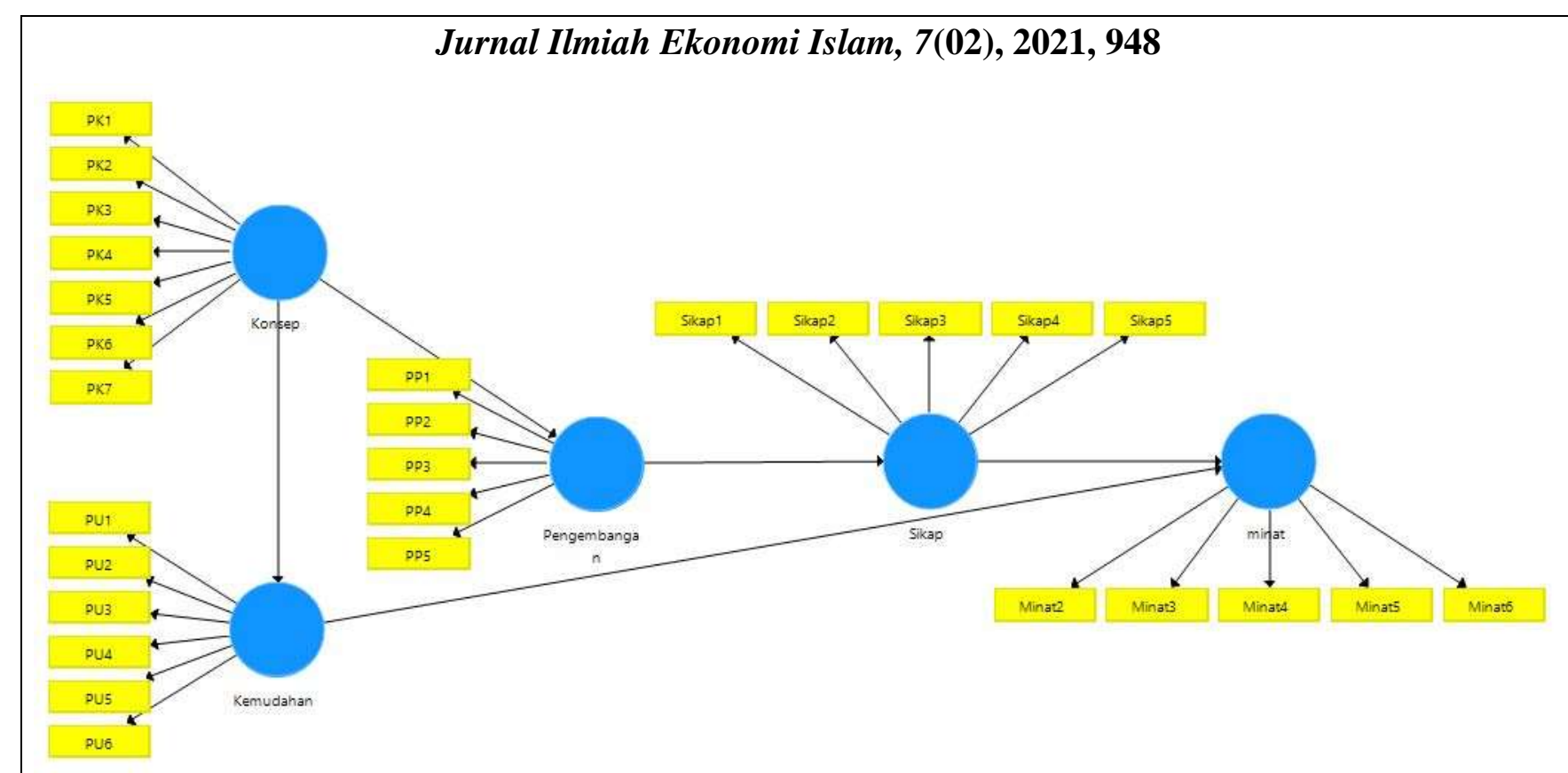

Figure 3. Research Construct

Source: Result of Data Processing from Smart PLS Ver. 3

The scheme that the researcher design was a modified scheme, which is why there need to be a test in regards to whether or not the model is suitable to use. The result of data processing of the fit model from construct above is posted below:

Table 3. Fit Model Data Processing

\begin{tabular}{|c|c|c|}
\hline & Saturated Model & $\begin{array}{c}\text { Estimated } \\
\text { Model }\end{array}$ \\
\hline SRMR & 0.084 & 0.102 \\
\hline d_ULS & 2.894 & 4.195 \\
\hline d_G1 & 3.601 & 3.754 \\
\hline d_G2 & 2.981 & 3.117 \\
\hline Chi-Square & 646.440 & 659.596 \\
\hline NFI & 0.664 & 0.657 \\
\hline
\end{tabular}

Source: Result of Data Processing from Smart PLS

Ver 3

In the SEM model tested using Smart PLS has two models that need to produce significant results so that the said test can be said a success. The model namely: Measurement Model (Outer Model) which is

a measurement model that connected indicator with its latent variables and Structural Model (Inner Model) which is a structural model that connected between latent variables.

Outer model in simply put tested how the indicator, in this case the questions from the questionnaire, connected with its latent variable. Indicator used in this research is reflective indicator that has characteristics such as: the direction of causality from latent variable to the indicator, between indicators can correlate (instrument has to have consistency reliability), dismissing one indicator doesn't change the meaning and definitions of variables measured. The example of this would be attitude and intention. Therefore, the test used in this model is Composite Reliability, Average Variance Extracted (AVE) and Cronbach Alpha. Those three tests were used to test the reliability and validity of question indicator from its latent variable. Below is the result of the outer model research test:

Table 4. Outer Model Test Result

\begin{tabular}{|c|c|c|c|c|}
\hline & $\begin{array}{c}\text { Cronbach's } \\
\text { Alpha }\end{array}$ & rho_A & $\begin{array}{c}\text { Composite } \\
\text { Reliability }\end{array}$ & $\begin{array}{c}\text { Average Variance } \\
\text { Extracted (AVE) }\end{array}$ \\
\hline Perceived Ease of Use & 0.935 & 0.948 & 0.949 & 0.757 \\
\hline Perceived Concept & 0.915 & 0.919 & 0.933 & 0.664 \\
\hline Perceived Expansion & 0.958 & 0.960 & 0.968 & 0.857 \\
\hline Attitude & 0.901 & 0.908 & 0.927 & 0.717 \\
\hline Interest & 0.913 & 0.919 & 0.935 & 0.741 \\
\hline
\end{tabular}

Source: Result of Data Processing from Smart PLS Ver 3

Composite Reliability value required to pass is $>0.8$, in which the result above shows all variable shows the values are above 0.8 even all of them are above 0.9 . It means the indicator in latent variable has 
high reliability, which means every question indicator have almost the same stability from every respondents' answers. Then, the Average Variance Extended (AVE) test value required to pass is $>0.5$, in which the result above shows all latent variable pass the AVE test so that it can be said that the indicator from latent variable pass the AVE test which means the indicator from latent variable is valid or relevant to be asked to the respondents in this model. For reliability test, it is strengthened with the Cronbach Alpha test which value required to pass is $>0.6$. In the data processing above, it shows that the Cronbach Alpha test value reached 0.9 so that it can be said that the indicator in the latent variable has high reliability. But if we look at the reliability test result simultaneously, there is one indicator question that did not pass the test which is the variable of question indicator interest "I want to know more about the mosque alms donation online apps" thus that question is removed and this will not change the meaning from the latent variable. The result of simultaneous outer model test can be seen in the attachment.

Selanjutnya pengujian inner model (model structural) yaitu uji pada model structural yang dilakukan untuk menguji hubungan antara kontruk laten. Terdapat beberapa uji yang biasanya digunakan pada model ini yakni : $\mathrm{R}$ Square (koefisien determinasi) dan Estimate for Path Coeficients. Uji R Square menunjukkan adanya tingkat kemampuan variabel laten dalam menjelaskan variabel latennya yang dipengaruhi. Hasil olah data menunjukkan angka sebagai berikut:

The next step would be the inner model (structural model) test which is a test on structural model to test the relationship between constructed latent. There are some tests that are usually done in this model, which is: $\mathrm{R}$ Square (Determination coefficients) and Estimate for Path Coefficients. The $\mathrm{R}$ Square test shows there are degrees in latent variable ability in explaining its latent variables that are influenced. The result of the data shows these numbers:

Table 5. R Square Test Result

\begin{tabular}{|c|c|c|}
\hline & R Square & R Square Adjusted \\
\hline P. Ease of Use & 0.825 & 0.822 \\
\hline P. Expansion & 0.608 & 0.600 \\
\hline Attitude & 0.561 & 0.552 \\
\hline Interest & 0.692 & 0.679 \\
\hline
\end{tabular}

Source: Result of Data Processing from Smart PLS Ver 3

The data result above shows perceived ease of use variable shows value of 0.822 which means this variable can be explained with other latent variable by $82.2 \%$, meanwhile the rest is explained by other variable outside of mentioned latent variables. So is its latent variable, the number in the R. Square Adjusted column shows how well the ability of the latent variable explained the variable. When the latent variable can be explained in much more degree, rationally can be said that between these latent variables does have relationship or correlation between one another. This makes the assumptions stronger that between the latent variable does have correlation or influences to one another. The test of influence done on estimate for path coefficients test which is the value of path coefficients or the magnitude of the influence of constructed latent. Below is the result of the test for this research:

Table 6. Influence Analysis Test Result

\begin{tabular}{|c|c|c|c|c|c|}
\hline & $\begin{array}{c}\text { Original } \\
\text { Sample }\end{array}$ & $\begin{array}{c}\text { Sample } \\
\text { Mean }\end{array}$ & $\begin{array}{c}\text { Standard } \\
\text { Deviation }\end{array}$ & $\begin{array}{c}\text { T Statistic } \\
\text { (O/STDV) }\end{array}$ & P Values \\
\hline P. Ease of Use - Interest & 0.373 & 0.374 & 0.117 & 3.196 & 0.001 \\
\hline P. Concept - P. Ease of Use & 0.909 & 0.910 & 0.021 & 43.915 & 0.000 \\
\hline P. Concept - P. Expansion & 0.780 & 0.775 & 0.054 & 14.560 & 0.000 \\
\hline P. Expansion- Attitude & 0.749 & 0.758 & 0.063 & 11.907 & 0.000 \\
\hline Attitude - Interest & 0.531 & 0.539 & 0.103 & 5.172 & 0.000 \\
\hline
\end{tabular}

Source: Result of Data Processing from Smart PLS Ver 3

The passing value of influence test can be seen in $\mathrm{P}$ Values column, in which it can be said as a success if the value is less than 0.05 . The result above shows that all of the current assumptions from the researcher regarding the relationship and influences to every latent variable pass the test. It can be interpreted that the latent variable of perceived concept does influence the perceived ease of use and perceived development. Furthermore the perceived development does influence the society's attitude in which the latent 
variable of attitude does influence the interest. Moreover, the interest is also influenced by the latent variable of perceived ease of use in which in this hypothesis is taken from TAM construct. Other than from $\mathrm{P}$ Values column the hypothesis test result can be seen from $T$ Statistic column, in which the hypothesis can be said as a success if the value is bigger than the value of the $t$ table. But in this case the researcher only uses the $\mathrm{P}$ Values column.

It can be concluded that there are strong influences from society perception toward the interest in using the service that the researcher offers. In which if the perceived concept toward the online donation shows positive result then the perceived development toward the online donation will also be good, so does the perceived ease of use also will be influenced by the perceived concept. In which a good perceived concept will influenced the good attitude to do online donations. Furthermore, the perceived ease of use also influenced the interest just like how the attitude influenced the interest as well.

The researcher can take a conclusion that the society's interest toward the idea of $\mathrm{QR}$ donation service is influenced by their perceptions, thus there need to be a socialization toward the society about the launch of this service before it is publicized. So that the society can understand and thus implement it. Before any socializations to the society, there need to be a comprehension between the mosque's committee so that they can understand the urgency of this service. Hence, a coordination from the licensor of the QR code donation service to Dewan Masjid Indonesia is a must. What it means by licensor is Bank Indonesia who regulate the installment of financial technology No 19/12/PBI/2017. Thus, hopefully from that coordination the QR donation service can be optimized for the mosque. The launch of this service is not to replace the current alms management, but for an additional alternative for mosques (especially the big ones) in managing the donation funds.

\subsection{Mosque Empowerment for the Neighborhood}

The potential in alms fund accumulation in mosques can be seen in many activities that involves the neighborhood like praying together (shalat jamaah), recitations and others that involve the mosques in the neighborhood. Therefore it is normal when mosque become a strategic place to give solutions to problems that arise in the neighborhood (Aminudin, 2008). Considering the spiritual values are really strong in the mosque social activities. By increasing the alms fund in the mosque, hopefully it can increase the prosperity of the mosque and the neighborhood. By integrating it to one service in a form of Alms pay, we hope there will be data records from every mosques. With said data, the fund can circulate not only on certain mosques but can be used by mosques that needed it.

When it is known that one of the mosque have excess funds for its operational, meanwhile other mosques have little to no funds at all, it will be recorded so that the fund can be transferred to others. Therefore the fund can increase the continuity of the operational of every mosques. We expect to create empowerment between the mosque that later on can create impact to the neighborhood around the mosque. The empowerment itself based on Swift and Levin (1981) is the effort in re-allocating the power by changing the social structure or the effort in motivating and enforcing to make or create one entity to try to do it.

The funds collected when it reached the upper limit of mosque welfare there need to be fund allocation to increase the welfare in the neighborhood. Just like in the research done by Faizin (2015) Dakwah Islam Indonesia agency in empowering their organization create a policy to donate every $10 \%$ of their income. The result has helped build worship facility such as: 1500 mosques around Indonesia and helped other organizations. Therefore, we hope by accumulating the fund by cashless can increase the amount of alms fund in every mosque.

\section{CONCLUSION}

This research comes initially from the writer's restlessness in seeing the unavailability of online alms service in mosques, where in 4.0 eras online payment has been widespread in the society especially millennials. By qualitative research with phenomenological research technique we try to offer an alms online service in mosque using QR codes. This service is similar to most payment systems used by society nowadays, by using apps such as OVO, Go pay, Link Aja, T-cash and others. The service accommodate the alms in mosque where by this QR code, the donation will be charged directly from the donator's account which will be transferred to the mosque's account. The manifestation of this service need a synergy between Bank Indonesia, Otoritas Jasa Keuangan and Dewan masjid Indonesia as the regulator of this app. Furthermore, we also test the 


\section{Jurnal Ilmiah Ekonomi Islam, 7(02), 2021, 951}

interest of society toward the launch of this SQR service with quantitative method. The result shows millennials are interested in using the SQR service when there are good perceptions toward the service, therefore we can assume this service will be accepted positively in the future.

We recommend for the government to create a platform to accommodate alms donation by cashless that can directly goes to the mosque's account so that it can increase the fund that is collected by the mosque so they can have more welfare in the future.

\section{REFERENSI}

Agustiani, Hendriati. 2009. Psikologi Perkembangan (Pendekatan EkologiKaitannya dengan Konsep Diri dan Penyesuaian Diri pada Remaja). Bandung: Refika Aditama.

Ajzen, I. 1991. The Theory of Planned Behavior. Organizational Behavior andHuman Decision Processes, 50, 179-211. doi: 10.1016/07495978(91)90020-T.

Akhmad Fakhrurozi. 2018. Faktor-Faktor Yang Mempengaruhi Minat Menggunakan Mobile Banking Pada Mahasiswa Universitas Muhammadiyah Surakarta. UMS.

Aminudin, Teukeu. 2008. Masjid Dalam Pembangunan. Yogyakarta: UII.

Ardhiani, Lisa Noor. 2015. Analisis Faktor-Faktor Penerimaan Penggunaan Quipperschool.Com Dengan Menggunakan Pendekatan Technology Acceptance Model (Tam) Dan Theory Of Planned Behavior (Tpb) Di Sma Negeri 7 Yogyakarta. UNY.

Bank Indonesia. Bank Indonesia Mencanangkan Gerakan Nasional Non Tunai https://www.bi.go.id/id/ruang-media/siaranpers/pages/sp_165814.aspx. [Internet]. [diunduh 2019 Maret 06].

Davis, F. D. 1989. Perceived Usefulness, Perceived Ease of Use, and User Acceptance of Information Technology. MIS Quarterly, VOl. 13.

Dedi Kusdani. 2013. Pengaruh Faktor-faktor Persepsi terhadap Sikap dan Minat Penggunaan Layanan Internet (Studi Kasus pada Nasabah Perusahaan Jasa Asuransi). UT.

Dewi, S. 2014. Prospek Pembayaran Non Tunai Edisi 50. Newsletter Bank Indonesia.
Dreana, T. 2012. Analisis Faktor-Faktor yang Mempengaruhi Penerimaan Pengguna SIMAWEB di Fakultas Ekonomika dan Bisnis Universitas Diponegoro: Integrasi TAM dan TPB. Skripsi. Universitas Diponegoro.

Faizin. 2015. Pemberdayaan Ekonomi Umat Melalui Sedekah: Perspektif Lembaga Dakwah Islamiyah Indonesia. Jurnal Kontekstualita Vol. 30 No. 2.

Financial

Bisnis. https://finansial.bisnis.com/read/20180208/55/7 36617/bayar-non-tunai-gaya-hidup-milenial. [Internet]. [diunduh 2019 Maret 06]

Firdauzi, Indrawan. 2016. Pengaruh Kemampuan Finansial, Kemudahan dan Perilaku Konsumen terhadap MinatPenggunaan Uang Elektronik di Kota Yogyakarta. Skripsi. Yogyakarta (ID) . Universitas Negeri Yogyakarta.

Fitria, T. N. (2016). Kontribusi Ekonomi Islam Dalam Pembangunan Ekonomi Nasional. Jurnal Ilmiah Ekonomi Islam, 2(03).

Ghozali, Imam. 2008. Aplikasi Analisis Multivariate dengan Program SPSS. Semarang: Badan Penerbit Universitas Diponegoro

Gumiwang, Ringkang. 2018. Jorjoran Adu "Bakar Uang" Go-Pay dan Ovo. [Internet]. [diunduh 2019 Maret 06]. Tersedia pada: https://tirto.id/jorjoran-adu-bakar-uang-go-paydan-ovo-c8u1.

Karim, Adiwarman Azwar. 2001. Ekonomi Islam Suatu Kajian Kontemporer Cet. 1. Jakarta: Gema Insani Press.

Kompas.com.https://lifestyle.kompas.com/read/2013/ 01/07/12160526/.Cashless.Society.Gaya.Hidup. Generasi.Millenial. [Internet]. [diunduh 2019 Maret 06].

Muhtadi. 2006. Pemberdayaan Masjid untuk Pengentasan Kemiskinan. Republika. 27 September.

Murai, Jun , Hideki Sunahara, Hiroshi Esaki. 2008. Broadband Deployment in Japan. Ohmsa ltd ISBN $427490640 X$.

Nurmalasari, Ajeng. 2018. Analisis Faktor-faktor yang Mempengaruhi Minat Penggunaan T-Cash pada Mahasiswa Universitas Islam Indonesia. Skripsi. Universitas Islam Indonesia, Yogyakarta.

Outlook Zakat Indonesia. 2018. Pusat Kajian Badan Amil Zakat Nasional. 
Jurnal Ilmiah Ekonomi Islam, 7(02), 2021, 952

Rahayu, Rurie Wiedya. 2018. Pengaruh Presepsi Manfaat, Presepsi Kemudahan, Presepsi Risiko dan Inovasi Teknologi terhadap Aplikasi Go Pay dari PT. Gojek Indonesia ( Studi pada Masyarakat di Kabupaten Sleman dan Kota Yogyakarta). Skripsi. Universitas Islam Indonesia.

Rahman, A. 2018. Manfaatkan Teknologi QR Code, Bayar Zakat Lebih Mudah", akses 7 Novenber 2018, https://finansial.bisnis.com/read/20180708/90/8 14047/manfaatkanteknologi-qr-code-bayarzakat-bisa-lebih-mudah,

Ramdhani, Neila. 2011. Penyusunan Alat Pengukur Basis Theory of Planned Behaviour. Buletin Psikologo Vol. 19, No. 2.

Shadiq. 1988. Kamus Istilah Agama. Jakarta: CV Seinttarama.

Suryanto, Asep. 2016. Optimalisasi Fungsi dan Potensi Masjid: Model Pemberdayaan Ekonomi Masyarakat Berbasis Masjid di Kota Tasikmalaya. Jurnal Iqtishoduna Vol. 8 No. 2 ISSN:2252 5661.
Swift dan Levin. 1981. Statistics for Management Englewood Clift. N.J: Prentice Hall.

Taylor, S., \& Todd, P. A. 1995. Understanding Information Technology Usage: A Test of Competing Models. Information Systems Research (6:1), 144176.

Wahyuddin. 2006. Manajemen Penghimpunan dan Pendayagunaan Zakat, Infaq, Shadaqah (ZIS) dan Wakaf Uang Melalui Teknologi Informasi Pada LAZ PORTALINFAQ. Skripsi. UIN Syarif Hidayatullah Jakarta.

Warta

Ekonomi. https://www.wartaekonomi.co.id/read174645/ini -6-manfaat-transaksi-nontunai-versi-bi.html. [Internet]. [diunduh 2019 Maret 06].

Warta ekonomi. https://www.wartaekonomi.co.id/read169084/mi lenial-indonesia-lebih-suka-transaksinontunai.html. [Internet]. [diunduh 2019 Maret 06].

Zaenudin, Ahmad. 2017. Profil Konsumen Belanja Online di Indonesia. [Internet]. [diunduh 2019 Maret 06]. Tersedia pada: https://tirto.id/profilkonsumen-belanja-online-di-indonesia-cuEG 